\title{
Quercetin as an Auxiliary Endodontic Irrigant for Root Canal Treatment: Anti-Biofilm and Dentin Collagen-Stabilizing Effects In Vitro
}

\author{
Zhuo Liu ${ }^{1,2,+}$, Xiangli Feng ${ }^{3,+}$, Xiangyao Wang ${ }^{1,2}$, Shiyuan Yang ${ }^{1}$, Jing Mao ${ }^{1,2, * \mathbb{D}}$ and Shiqiang Gong ${ }^{1,2, * \mathbb{D}}$ \\ 1 Center of Stomatology, Tongji Hospital, Tongji Medical College, Huazhong University of Science and \\ Technology, Wuhan 430030, China; liuzhuo@hust.edu.cn (Z.L.); m202076256@hust.edu.cn (X.W.); \\ yangshiyuan1996@sjtu.edu.cn (S.Y.) \\ 2 Hubei Province Key Laboratory of Oral and Maxillofacial Development and Regeneration, \\ Wuhan 430022, China \\ 3 Department of Stomatology, Hubei Provincial Hospital of TCM, Wuhan 430061, China; \\ doctorfengxiangli@163.com \\ * Correspondence: maojing@hust.edu.cn (J.M.); gsq@hust.edu.cn (S.G.); Tel.: +86-27-8366-3225 (S.G.) \\ + These authors contributed equally to this work.
}

check for updates

Citation: Liu, Z.; Feng, X.; Wang, X.; Yang, S.; Mao, J.; Gong, S. Quercetin as an Auxiliary Endodontic Irrigant for Root Canal Treatment: Anti-Biofilm and Dentin Collagen-Stabilizing Effects In Vitro. Materials 2021, 14, 1178. https:// doi.org/10.3390/ma14051178

Academic Editors: Edgar Schäfer and Teofil Jesionowski

Received: 23 January 2021

Accepted: 25 February 2021

Published: 3 March 2021

Publisher's Note: MDPI stays neutral with regard to jurisdictional claims in published maps and institutional affiliations.

Copyright: (c) 2021 by the authors. Licensee MDPI, Basel, Switzerland. This article is an open access article distributed under the terms and conditions of the Creative Commons Attribution (CC BY) license (https:/ / creativecommons.org/licenses/by/ $4.0 /)$.

\begin{abstract}
Bacterial reinfection and root fracture are the main culprits related to root canal treatment failure. This study aimed to assess the utility of quercetin solution as an adjunctive endodontic irrigant that does not weaken root canal dentin with commitment anti-biofilm activity and biosafety. Based on a noninvasive dentin infection model, dentin tubules infected with Enterococcus faecalis (E. faecalis) were irrigated with sterile water (control group), and 0, 1, 2, 4 wt\% quercetincontaining ethanol solutions. Live and dead bacteria percentages in E. faecalis biofilms were analyzed by confocal laser scanning microscopy (CLSM). Elastic modulus, hydroxyproline release and X-ray photoelectron spectroscopy (XPS) characterization were tested to evaluate the irrigants' collagenstabilizing effect. The cytotoxicity was tested by CCK-8 assay. Quercetin increased the proportion of dead bacteria volumes within E. faecalis and improved the flexural strength of dentin compared to control group $(p<0.05)$. Quercetin-treated dentin matrix had less elasticity loss and hydroxyproline release after collagenase degradation $(p<0.05)$. Moreover, quercetin solutions revealed an increase in the C-O peak area under both C1s and O1s narrow-scan spectra of XPS characterization, and no cytotoxicity $(p>0.05)$. Quercetin exhibited anti-biofilm activity, a collagen-stabilizing effect with cytocompatibility, supporting quercetin as a potential candidate for endodontic irrigant.
\end{abstract}

Keywords: antibacterial activity; endodontic irrigant; enterococcus faecalis; quercetin; root canal

\section{Introduction}

Root canal treatment is the method of choice for treating oral diseases associated with pulp and periapical infection. Endodontic microsurgery is often the last option to resolve persistent lesions with etiology related to complex root canal anatomy when non-surgical treatment is not effective [1]. The success of these endodontic treatments mainly relies on the thorough chemo-mechanical debridement of the infected root canals through the effective use of disinfectants and instrumentation, followed by sealing the enlarged, disinfected canals with appropriate root filling materials [2]. However, the bacterial elimination efficacy of root canal treatment is often compromised due to various reasons, such as untouched residual debris, and incomplete root canal filling that would allow secondary bacterial colonization [3-5]. In an ocean of failure cases, Enterococcus faecalis (E. faecalis) has been reported to present in the root canal as a biofilm alone or as the predominant bacterial specie [6-8]. In this regard, besides meticulous instrumentation, auxiliary endodontic medicaments (e.g., calcium hydroxide) and irrigants (e.g., sodium hypochlorite) with antibacterial activity are adopted by clinicians during root canal treatment, in order 
to disinfect the canal system and prevent reinfection. However, the risk of using these disinfectants is that they will cause changes in the chemical composition of the dentin (e.g., the biodegradation of demineralized dentin collagen) as long as disinfectants are applied in high concentrations for long periods $[9,10]$. In turn, these changes reduced the biomechanical properties of dentin, such as microhardness [11-13], flexural strength [14,15], modulus of elasticity $[15,16]$, and the fracture resistance under normal masticatory loads. This is considered to be another risk factor for the root canal treatment failure. Therefore, endodontic disinfectants that kill E. faecalis whilst not compromising the biomechanical properties of dentin are in great demand [17-20].

Quercetin (Figure 1) is a natural bioflavonoid found in abundance in food and beverages such as broccoli, onions, tea, apples, and berries. It has many biological and pharmacological benefits, such as anti-inflammatory, anti-allergic and antioxidant properties, owing to its ability to remove reactive oxygen species and superoxide anions [21-23]. It has also been proved to be an effective antimicrobial agent against a broad range of pathogenic microorganisms, including E. faecalis [24-28]. In the field of biomaterial and bioengineering, quercetin has also been widely utilized for biomodification of scaffold materials due to its glutaraldehyde-comparable collagen-crosslinking capability and superior cytocompatibility [29]. Recently, it has been doped into dentin adhesive with the aim to improve the long-term performance of the resin-dentin bonding interface, wherein quercetin protects the structural integrity of dentin collagen from biodegradation by crosslinking the apatite-depleted collagen [30]. The anti-biofilm and collagen-stabilizing effects of quercetin make it a potential candidate for an endodontic irrigant.

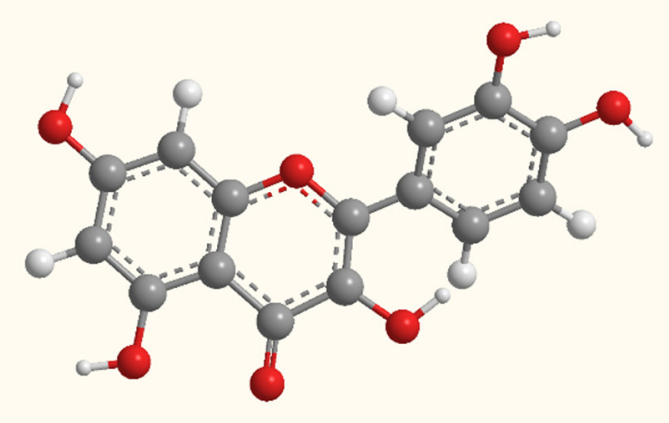

Figure 1. Quercetin's chemical structure (molecular formula: $\mathrm{C}_{15} \mathrm{H}_{10} \mathrm{O}_{7}$ ).

The objective of the current study was to explore the feasibility of quercetin solution as an auxiliary endodontic irrigant with anti-biofilm activities against $E$. faecalis and a dentin collagen-stabilizing capability. We evaluated the anti-biofilm effect of quercetin by confocal laser scanning microscopy (CLSM), based on an in vitro dentin infection model with intensive and ubiquitous E. faecalis infection in the dentin tubules [31]. The dentin collagen-stabilizing capability of quercetin solution was assessed with regard to biomechanical properties and biodegradation resistance of dentin collagen. Moreover, biomodification of demineralized dentin collagen by quercetin was characterized by X-ray photoelectron spectroscopy (XPS), and the cytotoxicity of quercetin irrigant was tested on human dental pulp cells (HDPs). The null hypotheses are quercetin irrigant (1) does not kill E. faecalis or inhibit the growth of biofilm; (2) does not enhance dentin collagen's modulus of elasticity and reduce the loss of modulus and hydroxyproline release; (3) shows cytotoxicity on HDPs.

\section{Materials and Methods}

\subsection{Experimental Irrigant Preparation and Tooth Collection}

Due to the poor solubility in water, we selected pure ethanol as the solvent for quercetin in our study [32]. Quercetin powder (Sigma-Aldrich, St. Louis, MO, USA) 
was directly added to $100 \%$ ethanol, followed by water-bath heating at $37^{\circ} \mathrm{C}$ for $15 \mathrm{~min}$. All experiments were conducted based on the following 5 groups: sterile water (control group), $0 \mathrm{wt} \%$ (ethanol group), $1 \mathrm{wt} \%, 2 \mathrm{wt} \%$ and $4 \mathrm{wt} \%$ quercetin groups.

All methodologies applied in this study were performed in accordance with the relevant guidelines and regulations [33]. Human single-rooted teeth (antibacterial test and XPS characterization) and third molars (biomechanical test) extracted for the orthodontic treatment were collected with informed consent. Different fresh and intact human teeth were obtained for the following purposes: (a) 10 single root premolars for antimicrobial test; (b) 40 dentin beams $\left(1.2 \times 0.8 \times 6.0 \mathrm{~mm}^{3}\right)$ prepared from the third molars for biomechanical test; and (c) 5 premolars for XPS examination. All teeth were stored in saline solution at $4{ }^{\circ} \mathrm{C}$ for no more than one month [34].

\subsection{Antibacterial Test}

\subsubsection{Sample Preparation}

As previously described [35], each single-rooted tooth was horizontally sectioned $1 \mathrm{~mm}$ below the cementoenamel junction using a low-speed diamond saw (SYJ-150, Kejin, Shenyang, China) at $300 \mathrm{rpm}$ under water cooling. Then, the root was cut in parallel with the occlusal surface of the teeth to obtain a cylindrical root dentin block with a length of $4 \mathrm{~mm}$. The root canals inside the dentin block were enlarged to a diameter of $1.5 \mathrm{~mm}$ using a size 6 Gates Glidden drill (Tulsa Dentsply, Tulsa, OK, USA) at 300 rpm under water cooling. A groove was made in the middle of each cylindrical dentin block using a low-speed handpiece (Tulsa Dentsply, Tulsa, OK, USA) with a round bur. Then the dentin block was fractured with a blade and a hammer into 2 semi-cylindrical halves. The semi-cylindrical halves were ground to $2 \mathrm{~mm}$ thickness by 600-grit silicon paper. The specimens were then shaped using a low-speed handpiece with a fine carbide bur at $300 \mathrm{rpm}$ under water cooling to obtain refined semi-cylindrical specimens with a size approximately $4 \times 4 \times 2 \mathrm{~mm}^{3}$, so that they can be placed in a $0.45 \mu \mathrm{m}$ pore size filter tube (Pall Corporation, Ann Arbor, MI, USA) [31].

The specimens were rinsed with a $5.25 \%$ sodium hypochlorite and $6 \%$ citric acid ( $\mathrm{pH}$ 4.0) solution in an ultrasonic bath (Sankei Giken Industry Co Ltd., MIE, Tokyo, Japan) for $4 \mathrm{~min}$ to remove the smear layer, and were rinsed in water for $1 \mathrm{~min}$. Each specimen was placed in a filter tube with the canal side up. The gap between the specimen and the inner walls was sealed with resin composite (Kerr Co, Orange, CA, USA).

\subsubsection{Infection of Dentin}

E. faecalis ATCC 29,212 (American Type Culture Collection, Manassas, VA, USA) was cultured on brain-heart infusion (BHI) agar (Becton-Dickinson, Sparks, MD, USA) plates at $37^{\circ} \mathrm{C}$ overnight. Then, the bacteria were suspended in a BHI broth and standardized spectrophotometrically to $3 \times 10^{6}$ colony-forming units $(\mathrm{CFU}) / \mathrm{mL}\left(\mathrm{OD}_{405}=0.05\right)$ [31]. Then $500 \mu \mathrm{L}$ of the bacterial suspension was added into each filter tube wherein the dentin specimen had been placed. The tubes were centrifuged at forces of $1400 \times g, 2000 \times g$, $3600 \times g$, and $5600 \times g$ in a sequence twice each for $5 \mathrm{~min}$. After dumping the last centrifugal solution, the upper compartment was refilled with a fresh $500 \mu \mathrm{L}$ of bacterial suspension before the next force of centrifugation. Ten filter tubes containing specimens were incubated in a sterile $\mathrm{BHI}$ broth in air at $37^{\circ} \mathrm{C}$ for 1 week.

After incubation, the infected specimens were taken out from the filter tube and the resin composite was removed. The specimens were rinsed by sterile water for $1 \mathrm{~min}$ and air-dried. Then, nail varnish was used to seal the cemental sides of the dentin pieces. Subsequently, a total of 20 specimens were randomly distributed into 5 groups with different irrigants as previously described: control group, ethanol group, $1 \mathrm{wt} \%, 2 \mathrm{wt} \%$ and $4 \mathrm{wt} \%$ quercetin groups. A droplet $(50 \mu \mathrm{L})$ of irrigant was placed on the pulp side of the dentin pieces for $3 \mathrm{~min}$. Then, the specimens were rinsed with sterile water for $1 \mathrm{~min}$ and fractured vertically through the root canal into two halves to expose a fresh surface of longitudinally fractured dentinal tubules for CLSM examination. 


\subsubsection{Confocal Laser Scanning Microscopy (CLSM) Examination}

The fractured dentin specimens were stained with LIVE/DEAD BacLight Bacterial Viability Kit (Molecular Probes, Eugene, OR, USA) according to the manufacturer's instructions. The excitation/emission wavelengths of SYTO 9 (green fluorescent dye that stains live bacteria) and propidium iodide (PI, red fluorescent dye that stains dead bacteria) were $480 / 500 \mathrm{~nm}$ and $490 / 634 \mathrm{~nm}$, respectively. The mounted specimens were observed by CLSM (LSM 710, Zeiss, Oberkochen, Germany) using a $20 \times$ lens with an additional zoom of $2 \times$. Under the microscope, the border of root canal for each specimen was first located, and then five randomly selected locations starting from the root canal border were scanned. For any scanned location, one image stack containing 20 slices were acquired at $0.5-\mu \mathrm{m}$ z-step (the distance between two adjacent images of a stack). Three-dimensional reconstructions and volume calculation of all image stacks were performed using Imaris 7.2 software (Bitplan Inc., St Paul, MN, USA). The proportion of dead bacteria within the E. faecalis biofilms was represented by the volume ratio of red fluorescence to green and red fluorescence.

\subsection{Biomechanical Test}

\subsubsection{Modulus of Elasticity of Demineralized Dentin before and after Irrigation}

Forty dentin beams $\left(1.2 \times 0.8 \times 6.0 \mathrm{~mm}^{3}\right)$ free of notches and cracks were sectioned from the root dentin of the third molars as previously described [36]. They were completely demineralized in $0.5 \mathrm{M}$ ethylenediaminetetraacetic acid (EDTA) $(\mathrm{pH}=7.5)$ for 7 days at $37^{\circ} \mathrm{C}$ and were thoroughly rinsed with distilled water for $10 \mathrm{~min}$. The demineralized beams were divided into 5 groups and immersed in 2-mL irrigants for $3 \mathrm{~min}$, followed by water-rinsing for $1 \mathrm{~min}$. A bacterial collagenase solution was prepared by dissolving bacterial collagenase (from Clostridium histolyticum, 125 collagen digestion units per mg solid; Sigma-Aldrich, Merck KGaA, Darmstadt, Germany) in a $0.4 \mathrm{M}$ ammonium bicarbonate-buffered solution $(\mathrm{pH}=7.9)$ at a concentration of $0.1 \%(\mathrm{~m} / \mathrm{m})$. The beams were incubated in the bacterial collagenase solution individually in a 96-well plate for $48 \mathrm{~h}$ at $37^{\circ} \mathrm{C}$. The modulus of the elasticity of all beams was estimated at baseline, after 3-min treatment in their irrigant solutions and after 48-h enzymatic hydrolysis through threepoint bending flexure test. The cross-head of the universal tester (EZ Graph, Shimadzu, Kyoto, Japan) is used at a rate of $1 \mathrm{~mm} / \mathrm{min}$ in a controlled range of up to $10 \%$ of stain [37]. The corresponding modulus of elasticity was calculated according to the formula using pressure-displacement curves.

$$
\mathrm{E}=\mathrm{mL}^{3} / 4 \mathrm{bT}^{3}(\mathrm{MPa})
$$

where $\mathrm{m}$ : slope; $\mathrm{L}(\mathrm{mm})$ : support arm spacing; $\mathrm{b}(\mathrm{mm})$ : sample width; $\mathrm{T}(\mathrm{mm})$ : sample thickness.

\subsubsection{Hydroxyproline (HYP) Release Assay}

After the aforementioned 48-h collagenase incubation, the dry mass of each beam was measured and the HYP content in the collagenase incubation medium was analyzed by using a HYP kit (Jiancheng, Nanjing, China). The HYP content was used to estimate the percentage of degraded collagen, based on the knowledge that $90 \%$ of the dry mass of demineralized dentin consists of type I collagen and that dentin collagen contains $9.6 \%$ of hydroxyproline [38]. The absorbance was measured at $550 \mathrm{~nm}$ with a spectrophotometer (Tecan Group, Männedorf, Switzerland) and the HYP released from each beam was represented by dividing the HYP by the dry weight of dentin beam ( $\mu \mathrm{g} \mathrm{HYP} / \mathrm{mg}$ dentin).

\subsection{X-ray Photoelectron Spectroscopy Characterization}

Demineralized dentin discs $\left(4 \times 4 \times 1 \mathrm{~mm}^{3}\right)$ were treated by different irrigants for $3 \mathrm{~min}$ each, and were rinsed with deionized water for $1 \mathrm{~min}$. Then, the samples were dried for $12 \mathrm{~h}$ in a vacuum pump (FY-4C-N, Value, Hangzhou, China). X-ray Photoelec- 
tron Spectrometer (ESCALAB250Xi, Thermo Fisher Scientific, Waltham, MA, USA) with monochromatic $\mathrm{Al} \mathrm{K} \alpha \mathrm{X}$-ray source was used to characterize the elemental distribution of $\mathrm{C} 1 \mathrm{~s}$ and $\mathrm{O} 1 \mathrm{~s}$ on the dried discs. Five sites of the fractured surfaces of each specimen were randomly selected for the analysis. The acquired data were analyzed using XPS PEAK 4.1 software for peaks of each element. The high resolution of $\mathrm{C} 1 \mathrm{~s}$ and O1s spectra was curve-fitted based on Gaussian-Lorentzian composite function with the background subtracted in Shirley mode.

\subsection{Cytotoxicity Evaluation with CCK-8 Assay}

Human dental pulp cells (HDPs) were a gift from the Department of Stomatology, Union Hospital, Huazhong University of Science and Technology. The cells were cultured in $\alpha$-MEM (HyClone, Logan, UT, USA) and $100 \mu \mathrm{g} / \mathrm{mL}$ of penicillin G-streptomycin at $37^{\circ} \mathrm{C}$ with $5 \% \mathrm{CO}_{2}$ in a humidified environment. The third passage of HDPs were seeded into 96-well plates (5000 cells per well) for $24 \mathrm{~h}$, followed by a 24 -h treatment with 100 -fold dilutions of the previous test solutions in $\alpha$-MEM. Thereafter, the Cell Counting Kit- 8 (MA0218-1, Meilunbio, Dalian, China) was performed according to the manufacturer's protocol for $4 \mathrm{~h}$ to assess cell viability (\%). The experiment was performed in quintuplicate. The experimental process was shown in Figure 2.

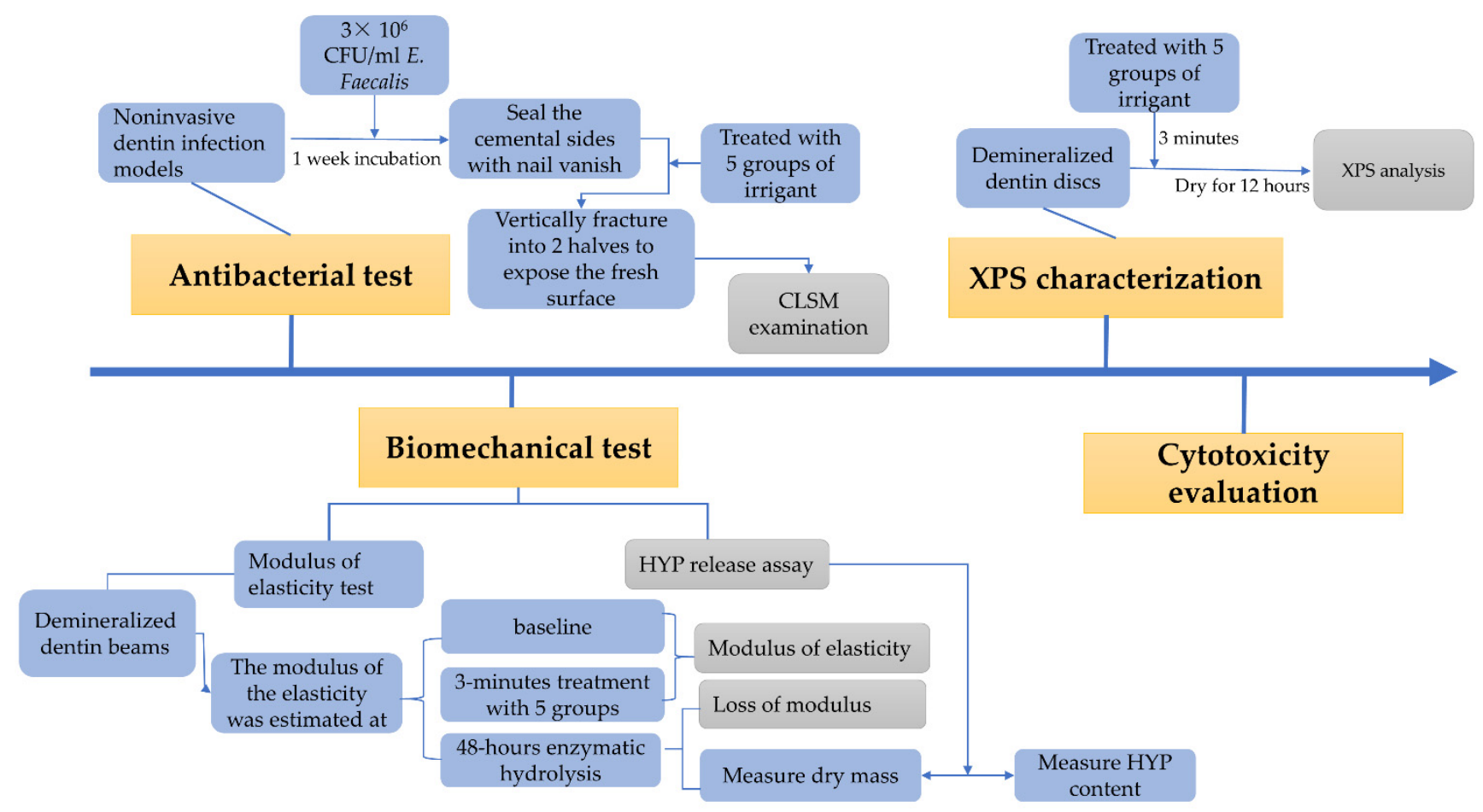

Figure 2. The flow chart for the experimental process. CFU: colony-forming units; HYP: hydroxyproline; XPS: X-ray photoelectron spectroscopy; CLSM: confocal laser scanning microscopy.

\subsection{Statistical Analysis}

Data are presented as the mean \pm standard deviation. Statistical analysis was performed using the SPSS 25.0 software (SPSS Inc., Armonk, New York, NY, USA) package at the $5 \%$ level of significance. All data were submitted to one-way analysis of variance (ANOVA) and complemented by Tukey's multiple comparison. Groups labeled with the same letters are not statistically different $(p>0.05)$. Power analysis was conducted to determine the sample size for each experiment and to project the power as 0.8 and significance level as 0.05 . 


\section{Results}

\subsection{Effect of Quercetin on E. faecalis}

The bacteria penetration from the root canal to dentin tubules after centrifugation and the anti-biofilm effect of each irrigant against E. faecalis are shown in Figure 3. The histogram represents the death cell rate of E. faecalis biofilm that grew in infected dentin tubules. There were statistically significant differences between the experimental and the control groups $(p<0.05)$. Both the pure ethanol and quercetin solutions showed obvious anti-biofilm effects, and as the concentration of the quercetin solution increased, the proportion of dead volumes of E. faecalis raised from $19.13 \%$ to $57.8 \%$, with a statistically significant difference $(p<0.05)$. The $4 \mathrm{wt} \%$ group $(57.8 \%)$ showed the strongest anti-biofilm activity $(p<0.05)$.

2D
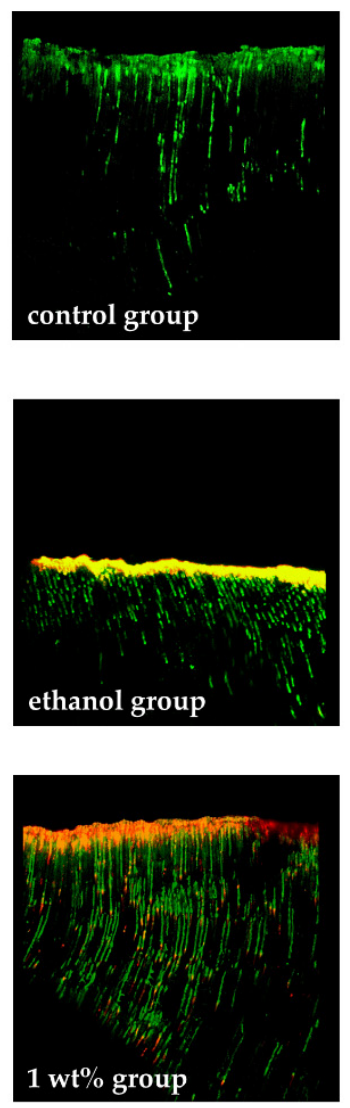

3D
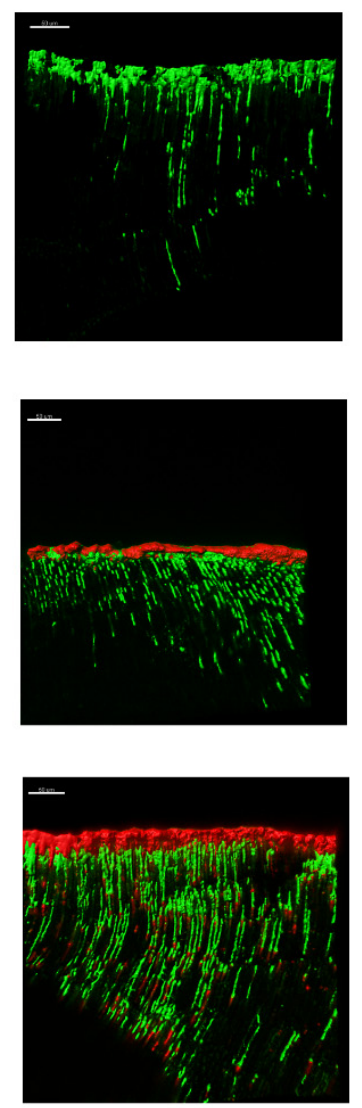

(a)
2D
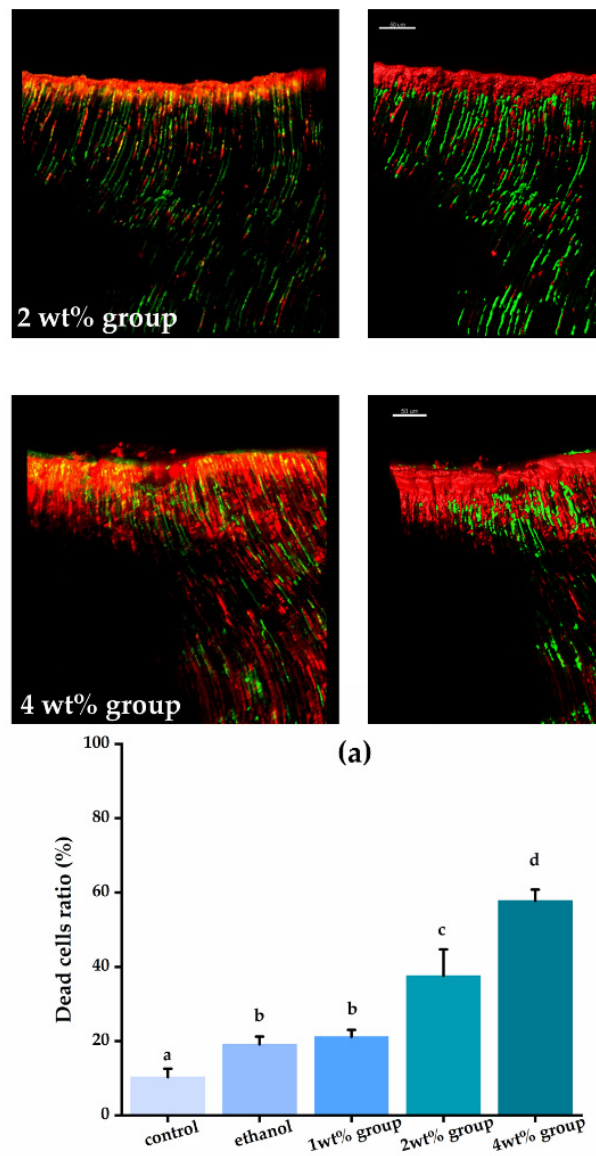

(b)
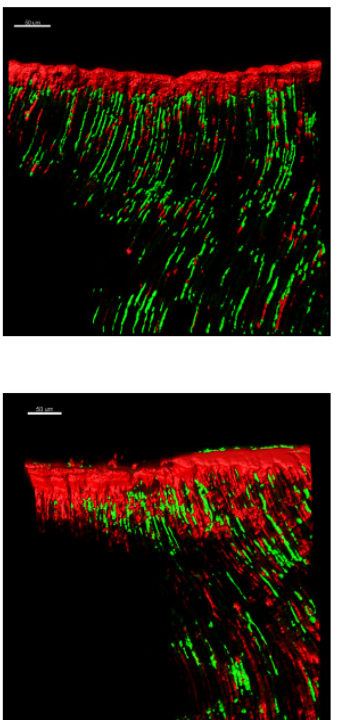

(a)$$
\text { ) }
$$

Figure 3. (a) Representative CLSM images of E. faecalis biofilms in dentinal tubules treated by different irrigants after live/dead staining and histogram showing dead cell ratio of bacteria biofilms from corresponding groups. For the CLSM images from each group, the image on the left is a 2-dimensional emerged image and the image on the right is a 3dimensional reconstruction. (b) Quantitation data of the percentage of live and dead area, groups with the same letters are not statistically different $(p>0.05)$.

\subsection{Effect of Quercetin on Dentin's Biomechanics}

Figure 4 shows that all quercetin groups had a significantly higher elastic modulus, and less modulus loss and HYP release than that of the control groups $(p<0.05)$. Demineralized dentin beams in the control and pure ethanol group had no significant change of modulus $(p>0.05)$ and had the most reduction in elastic modulus after enzymatic degradation $(p<0.05)$. However, dentin beams in the quercetin groups, in concentration between 1 to $4 \mathrm{wt} \%$, had a higher increase in elastic modulus after irrigant treatment $(p<0.05)$, and the 
lower loss of elastic modulus reduced after biodegradation $(p<0.05)$, ranging from $55.5 \%$ to $21.93 \%$. After 48 -h collagenase incubation, dentin beams from the control group released $520.9 \pm 115.6 \mu \mathrm{g}$ of $\mathrm{HYP} / \mathrm{mg}$ dentin, whilst beams irrigated by quercetin demonstrated a lower HYP release $(p<0.05)$, ranging from $88.15 \pm 37.6$ to $296.9 \pm 45.6 \mu \mathrm{g}$ of HYP/mg dentin. The improvement of the elasticity and biodegradation resistance of dentin was quercetin concentration-dependent $(p<0.05)$.

(a)

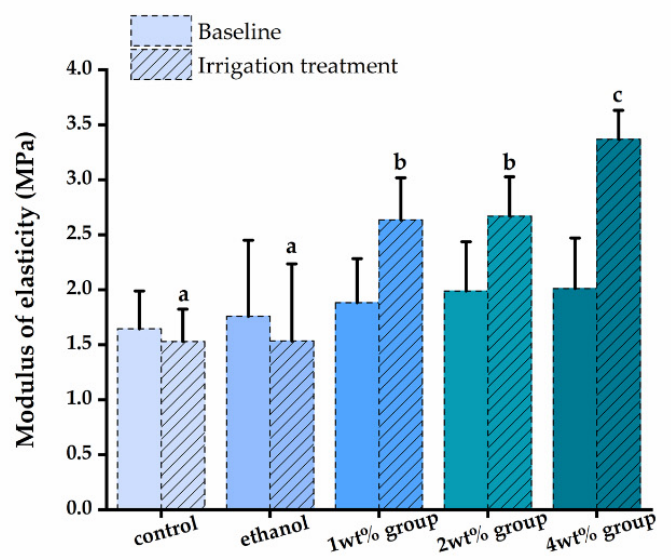

(c)

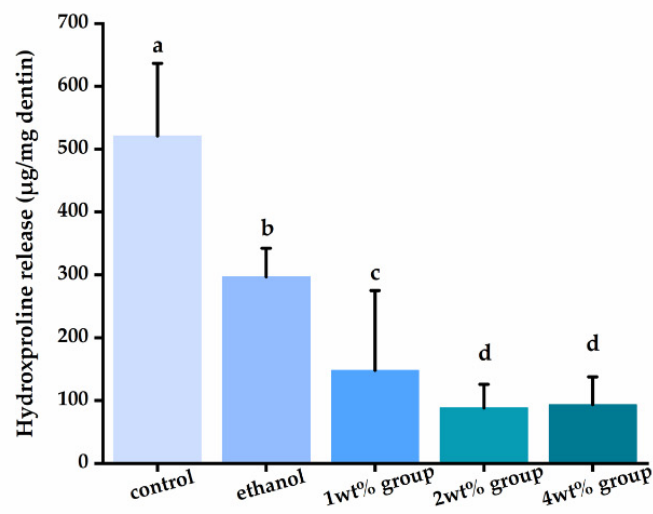

(b)

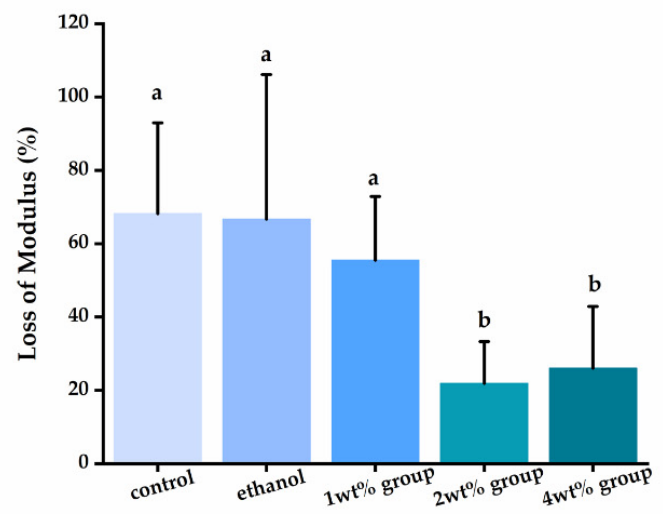

Figure 4. (a) The elastic modulus (MPa) of demineralized dentin beams at baseline, after irrigant treatment; (b) the loss of modulus (\%) of demineralized dentin beams after collagenase degradation compared to dentin beams treated by different irrigants; (c) the released HYP ( $\mu \mathrm{g} / \mathrm{mg}$ dentin) from dentin treated by different irrigants and challenged by collagenase. Groups with the same letters are not statistically different $(p>0.05)$.

\subsection{Characterization of Crosslinking between Quercetin and Collagen}

The XPS analysis characterized the chemical bonds of dentin collagen after quercetin biomodification as a surface-specific technique (Figure 5). The C1s spectra were curvefitted into three main peaks at 284.7, 285.9 and $288.0 \mathrm{eV}$, which are associated with carbons in the aliphatic chain of amino acid side chains $(\mathrm{C}-\mathrm{C} / \mathrm{C}-\mathrm{H})$, carbons at the $\alpha$-position of peptidic residues $(\mathrm{C}-\mathrm{O} / \mathrm{C}-\mathrm{N})$ and carbons in peptidic carbonyl and in carboxyl $(\mathrm{C}=\mathrm{O})$, respectively [39]. The O1s spectra exhibits two main peaks at 531.0 and $532.2 \mathrm{eV}$, which are dominantly attributed to the ketonic oxygen $(\mathrm{C}=\mathrm{O})$ and hydroxyl oxygen $(\mathrm{C}-\mathrm{O})$, respectively [40]. The detailed parameters of each peak of $\mathrm{C} 1 \mathrm{~s}$ and $\mathrm{O} 1 \mathrm{~s}$ spectra were listed in Table 1. Due to the abundance of hydroxyl groups in quercetin molecules, the C-O peak areas of both $\mathrm{C} 1 \mathrm{~s}$ and $\mathrm{O} 1 \mathrm{~s}$ spectra increased, in a quercetin concentration-dependent manner. The relative area of the $\mathrm{C}-\mathrm{O}$ peak under $\mathrm{C} 1 \mathrm{~s}$ from in the quercetin groups increased from $13.0 \%$ to $46.4 \%$, and the area of the C-O peak under O1s increased from $26.2 \%$ to $68.8 \%$, which indicated that quercetin with abundant phenolic hydroxyls was grafted onto dentin collagen. 
C1s
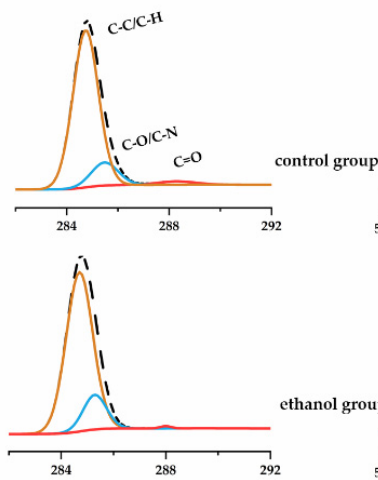

ethanol group
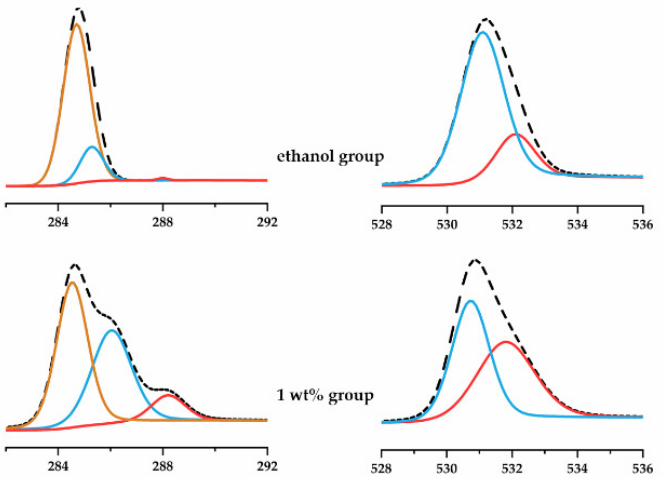

$1 \mathrm{wt} \%$ group
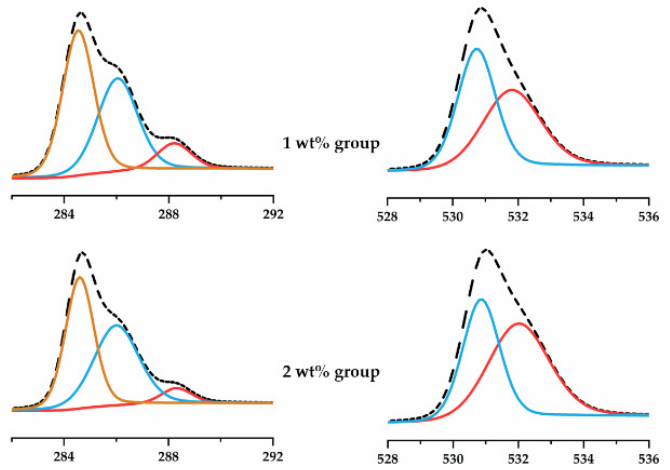

$2 w t \%$ group
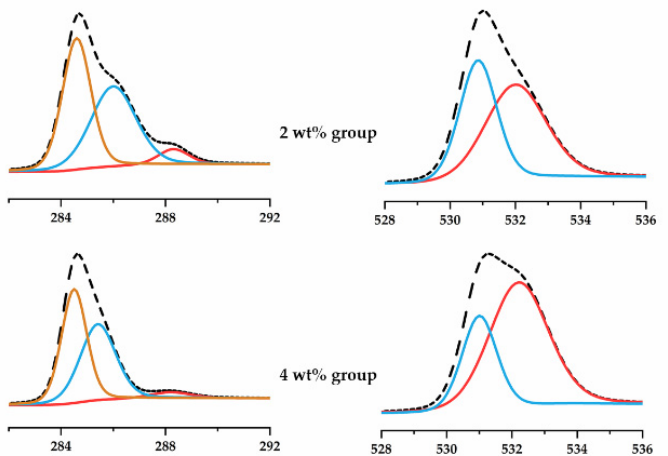

4 wt $\%$ group

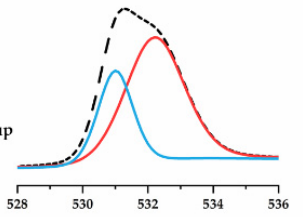

Figure 5. XPS high-resolution C1s (left column) and O1s (right column) spectra of dentin treated by irrigants.

Table 1. Data of C1s and O1s XPS narrow-scan spectra for dentin treated by irrigants.

\begin{tabular}{|c|c|c|c|c|c|}
\hline & \multicolumn{3}{|c|}{ C1s } & \multicolumn{2}{|c|}{ O1s } \\
\hline & $\mathrm{C}-\mathrm{C} / \mathrm{C}-\mathrm{H}$ & $\mathrm{C}-\mathrm{O}$ & $\mathrm{C}=\mathrm{O}$ & $\mathrm{C}=\mathrm{O}$ & $\mathrm{C}-\mathrm{O}$ \\
\hline \multicolumn{6}{|l|}{ Control group } \\
\hline $\mathrm{BE}^{\mathrm{a}}(\mathrm{eV})$ & 284.7 & 285.5 & 288.3 & 530.9 & 532.2 \\
\hline FWHM $^{\mathrm{b}}(\mathrm{eV})$ & 1.2 & 1.2 & 1.7 & 1.6 & 1.5 \\
\hline Area (\%) & 84.2 & 13 & 2.8 & 73.8 & 26.2 \\
\hline \multicolumn{6}{|l|}{ Ethanol group } \\
\hline $\mathrm{BE}(\mathrm{eV})$ & 284.7 & 285.3 & 288 & 531.1 & 532.1 \\
\hline FWHM (eV) & 1.2 & 1.1 & 1 & 1.6 & 1.4 \\
\hline Area (\%) & 83.6 & 15.9 & 0.5 & 79.1 & 21.9 \\
\hline \multicolumn{6}{|l|}{1 wt $\%$ group } \\
\hline $\mathrm{BE}(\mathrm{eV})$ & 284.5 & 286 & 288.2 & 530.7 & 531.9 \\
\hline FWHM (eV) & 1.4 & 1.8 & 1.5 & 1.4 & 2 \\
\hline Area (\%) & 49.7 & 40.6 & 9.7 & 55.9 & 44.1 \\
\hline \multicolumn{6}{|l|}{$2 w t \%$ group } \\
\hline $\mathrm{BE}(\mathrm{eV})$ & 284.6 & 286 & 288.3 & 530.9 & 532.2 \\
\hline FWHM (eV) & 1.3 & 2 & 1.4 & 1.4 & 2 \\
\hline Area $(\%)$ & 48 & 46 & 6 & 54.2 & 45.8 \\
\hline \multicolumn{6}{|l|}{$4 w t \%$ group } \\
\hline $\mathrm{BE}(\mathrm{eV})$ & 284.5 & 285.4 & 288.2 & 531 & 532.2 \\
\hline FWHM (eV) & 1.1 & 1.6 & 1.8 & 1.3 & 2.1 \\
\hline Area (\%) & 49.4 & 46.4 & 4.2 & 31.2 & 68.8 \\
\hline
\end{tabular}

a BE: binding energy; ${ }^{b}$ FWHM: full width at half maxima. 


\subsection{Effect of Quercetin on HDPs Viability}

Using human dental pulp cells, we investigated the cytotoxicity of quercetin solution (Figure 6). Following a 24-h exposure, the quercetin irrigants presented acceptable cytotoxicity compared with the control group $(p>0.05)$, even at the highest concentration tested.

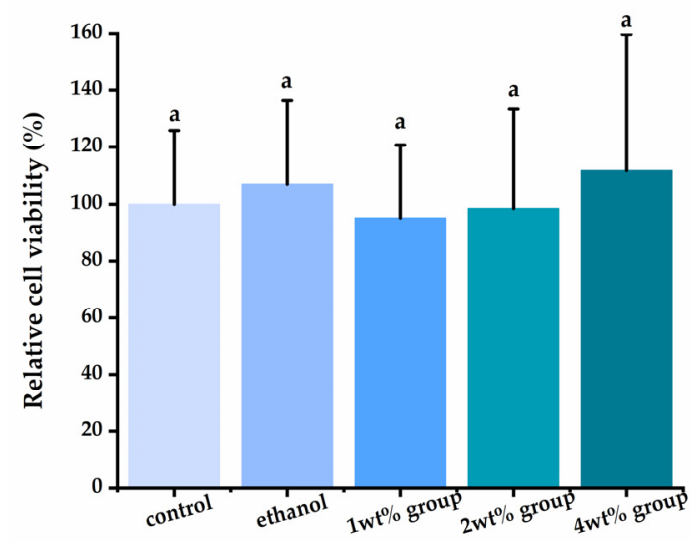

Figure 6. Evaluation of human dental pulp cells' (HDPs') viability exposed to different quercetincontaining mediums. Groups with the same letters are not statistically different $(p>0.05)$.

\section{Discussion}

An essential step in successful root canal treatment is to minimize the number of microorganisms in the root canal and dentin tubules through mechanical instrumentation and the use of irrigants with antimicrobial properties. However, due to the complexity of the root canal system (e.g., isthmus, lateral canals, root canal side, traffic branch, and root separation), it is difficult to remove all bacteria in the dentin tubules by routine mechanical methods or endodontic irrigants [41,42]. In addition, lurking in the root canal system, bacteria can withstand harsh environmental conditions and exhibits resistance to many antibiotics $[4,43]$. E. faecalis is physically and ecologically strong and can easily penetrate deep into dentin tubules $[44,45]$. Although several endodontic irrigants have been investigated, some compounds demonstrate many adverse effects such as compromised efficiency, cytotoxicity to mammal cells, allergic potential and even reduction in the mechanical properties of dentins [46-48]. Some studies have confirmed that chlorhexidine solution cannot infiltrate into dentinal tubules wherein a great number of infectious bacteria could hide for survival but can decrease the microhardness of dentin [11,42,49]. Sodium hypochlorite can penetrate the dentin and degrade the collagen matrix, eventually leading to root fracture [50,51]. Given this, the search for an adjunctive endodontic irrigant with strong antibacterial properties, the dentin collagen-stabilizing ability and good biocompatibility is paramount. In previous studies, quercetin has been proven to promote the long-time resin-dentin bonding [30,52]. In this study, we evaluated the utility of quercetin as auxiliary endodontic disinfectant and its effect on mechanical properties and degradation resistance of dentin, and rejected the proposed hypotheses according to the results.

In order to eliminate the effect of ethanol on the experimental results, $100 \%$ ethanol was utilized as the negative control since it was used to dissolve quercetin. Ethanol has a strong permeability and can infiltrate into the inner parts of bacteria and fungi to denature proteins crucial for their survival. Previous studies have proved that $95 \%$ ethanol had antibacterial effects against mono- and multispecies biofilms as an endodontic irrigant [53]. In addition, ethanol can improve the sealing ability of the root canal obturation decrease the leakage as a final irrigant, and has no effect on endodontic irrigants' antimicrobial properties [54-56]. Our experiments also show that ethanol solutions at appropriate concentrations are not significantly cytotoxic to HDPs, indicating that ethanol is a suitable solvent for our study.

By establishing an in vitro noninvasive model of infected root dentin tubules, we for the first time demonstrated the antibacterial ability of quercetin-containing ethanol 
solutions against E. faecalis biofilms hidden in the dentin tubules (Figure 3). With increased concentration, the antibacterial effect of the quercetin solution was enhanced with deeper penetration into the dentin tubules $(p<0.05)$. Quercetin is a natural polyphenolic flavonoid that presents in many kinds of plants. It has a strong antimicrobial ability against various Gram-positive bacteria, Gram-negative bacteria, and viruses [26,57]. It has been reported that quercetin can change the membrane potential to hinder bacteria's ability to synthesize adenosine triphosphate (ATP) and transporting material, thereby killing the bacteria [58]. However, it is hard to guarantee the antimicrobial ability in infected dentin tubes in vivo. Before the development of this noninvasive model, dentin block culture had been used as a very common method to simulate the presence, action, and eradication of bacteria in dentin tubules. However, it is difficult or impossible to obtain substantial, evenly distributed bacterial presence in dentin tubules with this method $[59,60]$. The application of this new model allows predictable, intensive and deep penetration of bacteria in dentin tubules, greatly aiding the study of dentin disinfection. In combination with the CLSM test, we not only directly visualized the bacteria, but also identified live and dead bacteria in infected dentins, which verified this in vitro noninvasive model as a suitable detection method with clinical relevance [7,61].

Our results showed that quercetin irrigant increased the biomechanical properties and biodegradation resistance of dentin collagen (Figure 4A,B). Because of the abundance of phenolic hydroxyl groups on its molecules, quercetin may interact with the collagen in root dentin via hydrogen bonds, van der Waals forces, electrostatic forces, and hydrophobic forces, thus maintaining the biostability of the demineralized collagen matrix after irrigant application [62], and improving the mechanical properties of demineralized dentin [63]. In the current work, we utilized XPS to confirm the quercetin-biomodificaiton of dentin collagen through the increased $\mathrm{C}-\mathrm{O}$ peak area under the $\mathrm{C} 1 \mathrm{~s}$ and $\mathrm{O} 1 \mathrm{~s}$ spectra (Figure 5 and Table 1) $[39,64]$. We also confirmed the resistance to collagenase degradation of quercetintreated dentin by HYP release assay. Dentin collagen treated by high concentrations (i.e., $2 w t \%, 4 w t \%)$ of quercetin showed the least HYP release (Figure 4C). Flavonoids, such as quercetin, inhibit both free and collagen-bound proteolytic enzymes in dentin [65] and down-regulate endogenous protease expression [66] to inactivate the protease, preventing free access of collagenase to sites containing collagen chains, thus increasing collagen's resistance to enzymatic degradation $[67,68]$. In addition, quercetin crosslinks with the exposed dentin to provide a mechanical barrier to the collagen matrix, with protection of the remaining dentin against acid attack erosion [69], abrasion [70] and erosion plus abrasion [71].

Since endodontic irrigants work directly in contact with human tissues in the clinic, they should be biocompatible to human cells and tissues. Quercetin is known to have good biosafety and low cytotoxicity [72]. According to the CCK-8 results (Figure 6), quercetincontaining ethanol solution with low concentration had no cytotoxic effect on human dental pulp cells. However, the other results argued the cytotoxic of quercetin with high concentration [73]. However, a previous study has emphasized that irrigants generally do not flow all the way to the root end in the positive pressure of irrigation technique [74]. Therefore, it is proper to use quercetin as an auxiliary endodontic irrigant under a proper isolation condition and technical conditions.

We believe quercetin has great potential for dental applications due to its multiple properties. For example, the success of the regenerative endodontic procedures (REP) also depends on increasing the thickness and length of the root canal wall and eliminating the infection in the root canal and apical area, which may indicate that quercetin as an auxiliary root canal irrigants has the potential application for REP [75]. However, there are two issues that need to be considered in our study. The results of antimicrobial tests and 48-h collagenase degradation study are not sufficient enough to draw conclusions about the long-term antimicrobial activity. Therefore, further studies are needed to assess the durability of dentin bio-modification and the antimicrobial activity of quercetin solutions. The second issue is that high concentrations of polyphenolic flavonoids, such as 
antioxidants, may affect the polymerisation reaction of resin root canal sealers in root canal treatment procedures [76,77]; further researches are needed to explore the reaction with endodontic materials.

\section{Conclusions}

Quercetin-containing ethanol irrigants showed a bactericidal effect against E. feacalis biofilms in dentin tubules and can maintain the mechanical strength of demineralized dentin and enhance biodegradation resistance. This proof-of-concept study demonstrated the utility of quercetin as a safe and reliable adjunctive root canal irrigant. Further clinical studies are still needed to evaluate its effectiveness in combination with other root canal disfectants, as well as the biosafety in vivo.

Author Contributions: Conceptualization, S.G. and J.M.; methodology, S.G.; software, Z.L.; validation, X.F. and X.W.; formal analysis, Z.L.; investigation, S.Y.; resources, Z.L.; data curation, X.F.; writing-original draft preparation, Z.L.; writing-review and editing, S.G.; visualization, J.M.; supervision, J.M.; project administration, S.G.; funding acquisition, S.G. All authors have read and agreed to the published version of the manuscript.

Funding: This work was financially supported by the National Natural Science Foundation of China (81771121).

Institutional Review Board Statement: The study was conducted according to the guidelines of the Declaration of Helsinki, and approved by the Institutional Review Board of TONGJI HOSPITAL, TONGJI MEDICAL COLLAGE, HUAZHONG UNIVERSITY OF SCIENCE AND TECHNOLOGY (No. TJ-C20171202).

Informed Consent Statement: Written informed consent has been obtained from the patients to publish this paper.

Data Availability Statement: Not applicable.

Acknowledgments: The authors are grateful to the Analytical and Testing Center, Wuhan University for performing XPS.

Conflicts of Interest: The authors declare no conflict of interest.

\section{References}

1. Palma, P.J.; Marques, J.A.; Casau, M.; Santos, A.; Caramelo, F.; Falacho, R.I.; Santos, J.M. Evaluation of Root-End Preparation with Two Different Endodontic Microsurgery Ultrasonic Tips. Biomedicines 2020, 8, 383. [CrossRef]

2. Chugal, N.; Mallya, S.M.; Kahler, B.; Lin, L.M. Endodontic Treatment Outcomes. Dent. Clin. N. Am. 2017, 61, 59-80. [CrossRef] [PubMed]

3. Wu, M.K.; Dummer, P.M.; Wesselink, P.R. Consequences of and strategies to deal with residual post-treatment root canal infection. Int. Endod. J. 2006, 39, 343-356. [CrossRef]

4. Vivacqua-Gomes, N.; Gurgel-Filho, E.D.; Gomes, B.P.; Ferraz, C.C.; Zaia, A.A.; Souza-Filho, F.J. Recovery of Enterococcus faecalis after single- or multiple-visit root canal treatments carried out in infected teeth ex vivo. Int. Endod. J. 2005, 38, 697-704. [CrossRef]

5. Siqueira, J.F., Jr.; Rôças, I.N.; Ricucci, D.; Hülsmann, M. Causes and management of post-treatment apical periodontitis. Br. Dent. J. 2014, 216, 305-312. [CrossRef]

6. Rôças, I.N.; Siqueira, J.F., Jr.; Santos, K.R. Association of Enterococcus faecalis with different forms of periradicular diseases. J. Endod. 2004, 30, 315-320. [CrossRef]

7. Duggan, J.M.; Sedgley, C.M. Biofilm formation of oral and endodontic Enterococcus faecalis. J. Endod. 2007, 33, 815-818. [CrossRef]

8. Love, R.M.; Jenkinson, H.F. Invasion of dentinal tubules by oral bacteria. Crit Rev. Oral Biol. Med. 2002, 13, 171-183. [CrossRef]

9. Hu, X.; Peng, Y.; Sum, C.P.; Ling, J. Effects of concentrations and exposure times of sodium hypochlorite on dentin deproteination: Attenuated total reflection Fourier transform infrared spectroscopy study. J. Endod. 2010, 36, 2008-2011. [CrossRef]

10. Yassen, G.H.; Chu, T.M.; Eckert, G.; Platt, J.A. Effect of medicaments used in endodontic regeneration technique on the chemical structure of human immature radicular dentin: An in vitro study. J. Endod. 2013, 39, 269-273. [CrossRef]

11. Oliveira, L.D.; Carvalho, C.A.; Nunes, W.; Valera, M.C.; Camargo, C.H.; Jorge, A.O. Effects of chlorhexidine and sodium hypochlorite on the microhardness of root canal dentin. Oral Surg. Oral Med. Oral Pathol. Oral Radiol. Endod. 2007, 104, e125-e128. [CrossRef]

12. Slutzky, I.; Maree, M.; Liberman, R.; Heling, I. Effect of sodium hypochlorite on dentin microhardness. J. Endod. 2004, 30, 880-882. [CrossRef] 
13. Aslantas, E.E.; Buzoglu, H.D.; Altundasar, E.; Serper, A. Effect of EDTA, sodium hypochlorite, and chlorhexidine gluconate with or without surface modifiers on dentin microhardness. J. Endod. 2014, 40, 876-879. [CrossRef]

14. Cullen, J.K.; Wealleans, J.A.; Kirkpatrick, T.C.; Yaccino, J.M. The effect of 8.25\% sodium hypochlorite on dental pulp dissolution and dentin flexural strength and modulus. J. Endod. 2015, 41, 920-924. [CrossRef]

15. Grigoratos, D.; Knowles, J.; Ng, Y.L.; Gulabivala, K. Effect of exposing dentine to sodium hypochlorite and calcium hydroxide on its flexural strength and elastic modulus. Int. Endod. J. 2001, 34, 113-119. [CrossRef] [PubMed]

16. Sim, T.P.; Knowles, J.C.; Ng, Y.L.; Shelton, J.; Gulabivala, K. Effect of sodium hypochlorite on mechanical properties of dentine and tooth surface strain. Int. Endod. J. 2001, 34, 120-132. [CrossRef]

17. Dotto, L.; Sarkis Onofre, R.; Bacchi, A.; Rocha Pereira, G.K. Effect of Root Canal Irrigants on the Mechanical Properties of Endodontically Treated Teeth: A Scoping Review. J. Endod. 2020, 46, 596-604.e593. [CrossRef]

18. Bello, Y.D.; Farina, A.P.; Souza, M.A.; Cecchin, D. Glycolic acid: Characterization of a new final irrigant and effects on flexural strength and structural integrity of dentin. Mater. Sci. Eng. C Mater. Biol. Appl. 2020, 106, 110283. [CrossRef] [PubMed]

19. Gandolfi, M.G.; Taddei, P.; Pondrelli, A.; Zamparini, F.; Prati, C.; Spagnuolo, G. Demineralization, Collagen Modification and Remineralization Degree of Human Dentin after EDTA and Citric Acid Treatments. Materials 2019, 12, 25. [CrossRef] [PubMed]

20. Generali, L.; Bertoldi, C.; Bidossi, A.; Cassinelli, C.; Morra, M.; del Fabbro, M.; Savadori, P.; Ballal, N.V.; Giardino, L. Evaluation of Cytotoxicity and Antibacterial Activity of a New Class of Silver Citrate-Based Compounds as Endodontic Irrigants. Materials 2020, 13, 5019. [CrossRef]

21. Salehi, B.; Machin, L.; Monzote, L.; Sharifi-Rad, J.; Ezzat, S.; Salem, M.; Merghany, R.; Mahdy, N.; Kılıç, C.; Sytar, O.; et al. Therapeutic potential of quercetin: New insights and perspectives for human health. ACS Omega 2020, 5, 11849-11872. [CrossRef]

22. Yilmaz, M.Z.; Guzel, A.; Torun, A.C.; Okuyucu, A.; Salis, O.; Karli, R.; Gacar, A.; Guvenc, T.; Paksu, S.; Urey, V.; et al. The therapeutic effects of anti-oxidant and anti-inflammatory drug quercetin on aspiration-induced lung injury in rats. J. Mol. Histol. 2014, 45, 195-203. [CrossRef] [PubMed]

23. Habtemariam, S.; Belai, A. Natural therapies of the inflammatory bowel disease: The case of rutin and its aglycone, Quercetin. Mini Rev. Med. Chem. 2018, 18, 234-243. [CrossRef]

24. Vipin, C.; Mujeeburahiman, M.; Ashwini, P.; Arun, A.B.; Rekha, P.D. Anti-biofilm and cytoprotective activities of quercetin against Pseudomonas aeruginosa isolates. Lett. Appl. Microbiol. 2019, 68, 464-471. [CrossRef] [PubMed]

25. Li, G.; Shen, X.; Wei, Y.; Si, X.; Deng, X.; Wang, J. Quercetin reduces Streptococcus suis virulence by inhibiting suilysin activity and inflammation. Int. Immunopharmacol. 2019, 69,71-78. [CrossRef]

26. Kaul, T.N.; Middleton, E., Jr.; Ogra, P.L. Antiviral effect of flavonoids on human viruses. J. Med. Virol 1985, 15, 71-79. [CrossRef]

27. Qayyum, S.; Sharma, D.; Bisht, D.; Khan, A.U. Identification of factors involved in Enterococcus faecalis biofilm under quercetin stress. Microb. Pathog. 2019, 126, 205-211. [CrossRef] [PubMed]

28. Das, S.; Batra, S.; Gupta, P.P.; Kumar, M.; Srivastava, V.K.; Jyoti, A.; Singh, N.; Kaushik, S. Identification and evaluation of quercetin as a potential inhibitor of naphthoate synthase from Enterococcus faecalis. J. Mol. Recognit. 2019, 32, e2802. [CrossRef]

29. Zhai, W.; Lü, X.; Chang, J.; Zhou, Y.; Zhang, H. Quercetin-crosslinked porcine heart valve matrix: Mechanical properties, stability, anticalcification and cytocompatibility. Acta Biomater. 2010, 6, 389-395. [CrossRef]

30. Yang, H.; Li, K.; Yan, H.; Liu, S.; Wang, Y.; Huang, C. High-performance therapeutic quercetin-doped adhesive for adhesive-dentin interfaces. Sci. Rep. 2017, 7, 8189. [CrossRef]

31. Ma, J.; Wang, Z.; Shen, Y.; Haapasalo, M. A new noninvasive model to study the effectiveness of dentin disinfection by using confocal laser scanning microscopy. J. Endod. 2011, 37, 1380-1385. [CrossRef] [PubMed]

32. Althans, D.; Schrader, P.; Enders, S. Solubilisation of quercetin: Comparison of hyperbranched polymer and hydrogel. J. Mol. Liq. 2014, 196, 86-93. [CrossRef]

33. World Medical Association. Declaration of Helsinki: Ethical principles for medical research involving human subjects. JAMA 2013, 310, 2191-2194. [CrossRef]

34. Poi, W.R.; Sonoda, C.K.; Martins, C.M.; Melo, M.E.; Pellizzer, E.P.; de Mendonça, M.R.; Panzarini, S.R. Storage media for avulsed teeth: A literature review. Braz. Dent. J. 2013, 24, 437-445. [CrossRef]

35. Yang, S.Y.; Liu, Y.; Mao, J.; Wu, Y.B.; Deng, Y.L.; Qi, S.C.; Zhou, Y.C.; Gong, S.Q. The anti-biofilm and collagen-stabilizing effects of proanthocyanidin as an auxiliary endodontic irrigant. Int. Endod. J. 2020, 53, 824-833. [CrossRef]

36. Marending, M.; Luder, H.U.; Brunner, T.J.; Knecht, S.; Stark, W.J.; Zehnder, M. Effect of sodium hypochlorite on human root dentine-Mechanical, chemical and structural evaluation. Int. Endod. J. 2007, 40, 786-793. [CrossRef]

37. Bedran-Russo, A.K.B.; Castellan, C.S.; Shinohara, M.S.; Hassan, L.; Antunes, A. Characterization of biomodified dentin matrices for potential preventive and reparative therapies. Acta Biomater. 2011, 7, 1735-1741. [CrossRef] [PubMed]

38. Tezvergil-Mutluay, A.; Agee, K.A.; Uchiyama, T.; Imazato, S.; Mutluay, M.M.; Cadenaro, M.; Breschi, L.; Nishitani, Y.; Tay, F.R.; Pashley, D.H. The inhibitory effects of quaternary ammonium methacrylates on soluble and matrix-bound MMPs. J. Dent. Res. 2011, 90, 535-540. [CrossRef]

39. Hu, Y.; Dan, W.; Xiong, S.; Kang, Y.; Dhinakar, A.; Wu, J. Development of collagen/polydopamine complexed matrix as mechanically enhanced and highly biocompatible semi-natural tissue engineering scaffold. Acta Biomater. 2016, 47. [CrossRef]

40. Wu, H.; Zhuo, L.; He, Q.; Liao, X.; Shi, B. Heterogeneous hydrogenation of nitrobenzenes over recyclable Pd(0) nanoparticle catalysts stabilized by polyphenol-grafted collagen fibers. Appl. Catal. A Gen. 2009, 366, 44-56. [CrossRef]

41. Kovac, J.; Kovac, D. Effect of irrigating solutions in endodontic therapy. Bratisl. Lek. Listy. 2011, 112, 410-415. [PubMed] 
42. Haapasalo, M.; Shen, Y.; Wang, Z.; Gao, Y. Irrigation in endodontics. Br. Dent. J. 2014, 216, 299-303. [CrossRef]

43. Kayaoglu, G.; Ørstavik, D. Virulence factors of Enterococcus faecalis: Relationship to endodontic disease. Crit. Rev. Oral Biol. Med. 2004, 15, 308-320. [CrossRef] [PubMed]

44. Fan, W.; Li, Y.; Liu, D.; Sun, Q.; Duan, M.; Fan, B. PLGA submicron particles containing chlorhexidine, calcium and phosphorus inhibit Enterococcus faecalis infection and improve the microhardness of dentin. J. Mater. Sci. Mater. Med. 2019, 30, 17. [CrossRef]

45. Zargar, N.; Rayat Hosein Abadi, M.; Sabeti, M.; Yadegari, Z.; Akbarzadeh Baghban, A.; Dianat, O. Antimicrobial efficacy of clindamycin and triple antibiotic paste as root canal medicaments on tubular infection: An in vitro study. Aust. Endod. J. 2019, 45, 86-91. [CrossRef]

46. Karpiński, T.M.; Szkaradkiewicz, A.K. Chlorhexidine-Pharmaco-biological activity and application. Eur. Rev. Med. Pharmacol. Sci. 2015, 19, 1321-1326.

47. Gomes, B.P.; Vianna, M.E.; Zaia, A.A.; Almeida, J.F.; Souza-Filho, F.J.; Ferraz, C.C. Chlorhexidine in endodontics. Braz. Dent. J. 2013, 24, 89-102. [CrossRef] [PubMed]

48. Pemberton, M.N.; Gibson, J. Chlorhexidine and hypersensitivity reactions in dentistry. Br. Dent. J. 2012, 213, 547-550. [CrossRef]

49. Hasheminia, S.; Farhad, A.R.; Saatchi, M.; Rajabzadeh, M. Synergistic antibacterial activity of chlorhexidine and hydrogen peroxide against Enterococcus faecalis. J. Oral Sci. 2013, 55, 275-280. [CrossRef]

50. Cecchin, D.; Soares Giaretta, V.; Granella Cadorin, B.; Albino Souza, M.; Vidal, C.M.P.; Paula Farina, A. Effect of synthetic and natural-derived novel endodontic irrigant solutions on mechanical properties of human dentin. J. Mater. Sci. Mater. Med. 2017, 28, 141. [CrossRef]

51. Gu, L.S.; Huang, X.Q.; Griffin, B.; Bergeron, B.R.; Pashley, D.H.; Niu, L.N.; Tay, F.R. Primum non nocere-The effects of sodium hypochlorite on dentin as used in endodontics. Acta Biomater. 2017, 61, 144-156. [CrossRef]

52. Porto, I.; Nascimento, T.G.; Oliveira, J.M.S.; Freitas, P.H.; Haimeur, A.; França, R. Use of polyphenols as a strategy to prevent bond degradation in the dentin-resin interface. Eur. J. Oral Sci. 2018, 126, 146-158. [CrossRef] [PubMed]

53. Suman, J.; Kuga, M.; Abreu, R.; Rosa, D.; Santini, M.; Grazziotin-Soares, R.; Montagner, F.; Só, M.; Reis, I. Antibacterial activity of chlorhexidine after final irrigation with ethanol: CLSM and culture-based method analysis. Microsc. Res. Tech. 2015, 78. [CrossRef] [PubMed]

54. Duarte, P.H.M.; da Silva, P.B.; Rosa, R.A.D.; Montagner, F.; Duarte, M.A.H.; Kuga, M.C.; Só, M.V.R. Effect of ethanol on the antimicrobial properties of chlorhexidine over oral biofilm. Microsc. Res. Tech. 2018, 81, 408-412. [CrossRef]

55. Stevens, R.W.; Strother, J.M.; McClanahan, S.B. Leakage and sealer penetration in smear-free dentin after a final rinse with $95 \%$ ethanol. J. Endod. 2006, 32, 785-788. [CrossRef] [PubMed]

56. Thiruvenkadam, G.; Asokan, S.; John, B.; Priya, P.G. Effect of $95 \%$ ethanol as a final irrigant before root canal obturation in primary teeth: An in vitro study. Int. J. Clin. Pediatr. Dent. 2016, 9, 21-24. [CrossRef]

57. Formica, J.V.; Regelson, W. Review of the biology of Quercetin and related bioflavonoids. Food Chem. Toxicol. 1995, 33, 1061-1080. [CrossRef]

58. Mirzoeva, O.K.; Grishanin, R.N.; Calder, P.C. Antimicrobial action of propolis and some of its components: The effects on growth, membrane potential and motility of bacteria. Microbiol. Res. 1997, 152, 239-246. [CrossRef]

59. Akpata, E.S.; Blechman, H. Bacterial invasion of pulpal dentin wall in vitro. J. Dent. Res. 1982, 61, 435-438. [CrossRef]

60. Parmar, D.; Hauman, C.H.; Leichter, J.W.; McNaughton, A.; Tompkins, G.R. Bacterial localization and viability assessment in human ex vivo dentinal tubules by fluorescence confocal laser scanning microscopy. Int. Endod. J. 2011, 44, 644-651. [CrossRef]

61. Shen, Y.; Stojicic, S.; Haapasalo, M. Bacterial viability in starved and revitalized biofilms: Comparison of viability staining and direct culture. J. Endod. 2010, 36, 1820-1823. [CrossRef] [PubMed]

62. Yang, X.; Wu, D.; Du, Z.; Li, R.; Chen, X.; Li, X. Spectroscopy study on the interaction of quercetin with collagen. J. Agric. Food Chem. 2009, 57, 3431-3435. [CrossRef] [PubMed]

63. Epasinghe, D.J.; Yiu, C.K.; Burrow, M.F.; Tsoi, J.K.; Tay, F.R. Effect of flavonoids on the mechanical properties of demineralised dentine. J. Dent. 2014, 42, 1178-1184. [CrossRef] [PubMed]

64. Saidin, S.; Chevallier, P.; Abdul Kadir, M.R.; Hermawan, H.; Mantovani, D. Polydopamine as an intermediate layer for silver and hydroxyapatite immobilisation on metallic biomaterials surface. Mater. Sci. Eng. C Mater. Biol. Appl. 2013, 33, $4715-4724$. [CrossRef]

65. Epasinghe, D.J.; Yiu, C.K.; Burrow, M.F.; Hiraishi, N.; Tay, F.R. The inhibitory effect of proanthocyanidin on soluble and collagen-bound proteases. J. Dent. 2013, 41, 832-839. [CrossRef] [PubMed]

66. Seseogullari-Dirihan, R.; Tekbas Atay, M.; Pashley, D.H.; Tezvergil-Mutluay, A. Inhibitory effect of curcuminoid pretreatments on endogenous dentin proteases. Dent. Mater. J. 2018, 37, 445-452. [CrossRef]

67. Neri, J.R.; Yamauti, M.; Silveira, F.D.D.; Mendonça, J.S.; Carvalho, R.M.D.; Santiago, S.L. Influence of dentin biomodification with epigallocatechin-3-gallate on the bond strength of self-etch adhesive: Twelve-month results. Int. J. Adhes. Adhes. 2016, 71, 81-86. [CrossRef]

68. Atabek, S..; Özden, A.N. Comparison of the effect of proanthocyanidin surface treatments on shear bond strength of different cements. Materials 2019, 12, 2676. [CrossRef]

69. Kato, M.T.; Leite, A.L.; Hannas, A.R.; Buzalaf, M.A. Gels containing MMP inhibitors prevent dental erosion in situ. J. Dent. Res. 2010, 89, 468-472. [CrossRef] [PubMed] 
70. Ganss, C.; Schlueter, N.; Hardt, M.; von Hinckeldey, J.; Klimek, J. Effects of toothbrushing on eroded dentine. Eur. J. Oral Sci. 2007, 115, 390-396. [CrossRef]

71. Buzalaf, M.A.; Kato, M.T.; Hannas, A.R. The role of matrix metalloproteinases in dental erosion. Adv. Dent. Res. 2012, 24, 72-76. [CrossRef] [PubMed]

72. Harwood, M.; Danielewska-Nikiel, B.; Borzelleca, J.F.; Flamm, G.W.; Williams, G.M.; Lines, T.C. A critical review of the data related to the safety of quercetin and lack of evidence of in vivo toxicity, including lack of genotoxic/carcinogenic properties. Food Chem. Toxicol. 2007, 45, 2179-2205. [CrossRef]

73. Conde, T.A.; Mendes, L.; Gaspar, V.; Mano, J.F.; Melo, T.; Domingues, M.R.; Duarte, I. Differential modulation of the phospholipidome of proinflammatory human macrophages by the flavonoids quercetin, naringin and naringenin. Molecules 2020, 25, 3460. [CrossRef] [PubMed]

74. Walters, M.J.; Baumgartner, J.C.; Marshall, J.G. Efficacy of irrigation with rotary instrumentation. J. Endod. 2002, 28, 837-839. [CrossRef] [PubMed]

75. Palma, P.J.; Martins, J.; Diogo, P.; Sequeira, D.; Ramos, J.C.; Diogenes, A.; Santos, J.M. Does apical papilla survive and develop in apical periodontitis presence after regenerative endodontic procedures? Appl. Sci. 2019, 9, 3942. [CrossRef]

76. Du, X.; Huang, X.; Huang, C.; Wang, Y.; Zhang, Y. Epigallocatechin-3-gallate (EGCG) enhances the therapeutic activity of a dental adhesive. J. Dent. 2012, 40, 485-492. [CrossRef]

77. Epasinghe, J.; Yiu, C.; Burrow, M. Effect of proanthocyanidin incorporation into dental adhesive on durability of resin-dentin bond. Int. J. Adhes. Adhes. 2015, 63, 145-151. [CrossRef] 